because he believes that reconciliation after the parties have filed divorce actions comes too late. He would substitute a pre-filing conciliation procedure. ${ }^{53}$ This plan actually amounts to "passive" reconciliation. If the parties are made to file a declaration of intent sixty days prior to the suit, it reasonably may be assumed that the "breaking point" has already been reached. Judge Miner merely proposed a "cooling off period" during which the parties are left to their own initiative. The Act, on the other hand, would have brought the resources of the community to bear in an active attempt to settle the difference between the parties.

Merely because acts like the Domestic Relations Act of I 949 are only part of a needed scheme of revision in the field of divorce, their enactment should not be defeated. Many of the problems in the area of divorce administration would be remedied, while the remaining substantive evils would be sharply defined, to be corrected by additional legislative action.

\title{
CONSEQUENTIAL DAMAGES AND "JUST COMPENSATION" IN FEDERAL CONDEMNATIONS
}

In federal condemnations ${ }^{x}$ the courts have applied the term "consequential damages" to all losses which have been excluded from the "just compensation" provision of the Fifth Amendment. ${ }^{2}$ In seizing private property the government has had to pay only for tangible interests actually taken ${ }^{3}$ and those intangible interests which the courts have held to be directly connected with the physical substance of the thing taken. ${ }^{4}$ No payment has been necessary for in-

s3 Miner, op. cit. supra note 34; Miner, Pre-Divorce Suit Conciliation, 36 Ill. Bar J. 207 (I948).

I Many state constitutions provide that compensation must be paid for property "taken or damaged." In such cases consequential damages may be recovered. 2 Nichols, Eminent Domain $\$ 6.4432[2]$ (1950). See Dolan, Consequential Damages in Federal Condemnation, 35 Va. L. Rev. 1059 (r949).

2 "[N]or shall private property be taken for public use without just compensation." United States v. Petty Motors Co., 327 U.S. 372 (1946); United States v. General Motors Corp., 323 U.S. 373 (1945); United States v. Powelson, 319 U.S. 266 (1943); Mitchell v. United States, 267 U.S. 34I (I925); Joslin Manufacturing Co. v. Providence, 262 U.S. 668 (I923); Omnia Co. v. United States, 26I U.S. 502 (1923).

3 United States v. Willow River Power Co., 324 U.S. 499 (r945); Redman v. United States, I36 F. 2 d 203 (C.A. 4th, I943); Karlson v. United States, 82 F. 2d 330 (C.A. 8th, I936).

4 United States v. Miller, $3{ }_{7} 7$ U.S. ${ }_{369}$ (I943); Campbell v. United States, 266 U.S. 368 (I924); Sharp v. United States, I9I U.S. 34I (I903); Stephenson Brick Co. v. United States, Iro F. $2 d$ d 360 (C.A. 5 th, I940). A typical payment for an injury directly connected with the condemnation is one for severance damages, i.e., the loss resulting from the decreased market value of a single tract of land because of the condemnation of part of it. This type of injury has always been compensated for. 
jury to good will, ${ }^{5}$ going-concern value, ${ }^{6}$ loss of profits ${ }^{7}$ or costs of removing furniture, machinery or fixtures. ${ }^{8}$

The reasoning underlying these exclusions is generally based either on the belief that such losses are too speculative for any sort of accurate determination, ${ }^{9}$ or on the theory that some of the rights attached to the condemned property exist apart from the physical asset, and, since they have not been taken, may readily be utilized..$^{20} \mathrm{~A}$ further reason is that some of these losses are said

5 Good will has been defined as the value of the business reputation of the firm and the patronage that accompanies it or as the value of anticipated future profits based on the past earnings of the business. See Metropolitan Bank v. St. Louis Dispatch Co., r49 U.S. 436 (I893); Orgel, Valuation under Eminent Domain 74 (x936); Simpson, Goodwill, 6 Encyc. Soc. Sci. 698 (I93I).

6 This consists of the intangible contributions to the value of the business such as patronage and increased earning power because of skillful management. Kimball Laundry v. United States, 338 U.S. I (I949). There is another concept of going-concern value synonymous with overhead costs. See Orgel, Valuation under Eminent Domain $\S$ I9r (ig36).

Going-concern value is noncompensable. United States v. Becktold Co., I29 F. $2 d 473$ (C.A. 8th, I942); Stull v. United States, 52 F. Supp. 598 (Pa., r943); In re Post Office Site in Borough of the Bronx, 2ro Fed. 832 (C.A. 2d, rgr4). When the government permanently condemns a business and intends to continue to operate it as a business, going-concern value must be paid for. Denver v. Denver Union Water Co., 246 U.S. I78 (IgI8); Omaha v. Omaha Water Co., 2r8 U.S. I80 (I9ro).

7 United States v. Petty Motors Co., 327 U.S. 372 (I946); United States v. General Motors Corp., 323 U.S. 373 (I945); United States v. City of New York, x68 F. 2d 387 (C.A. 2d, I948); United States v. Meyers, r9o Fed. 688 (D.C. Conn., rgrr); United States v. Certain Parcels of Land in City of San Diego, 54 F. Supp. 56I (Cal., r944).

8 United States v. Westinghouse, 339 U.S. 26r (I950); United States v. Petty Motors Co., 327 U.S. 372 (I946); United States V. General Motors Corp., 323 U.S. 373 (I945); Potomac Electric Power Co. v. United States, 85 F. 2 d 243 (App. D.C., r936), cert. den. 299 U.S. 565 (I936); Gershon Brothers Co.v. United States, 284 Fed. 849 (C.A. 5th, r922); United States v. Meyers, I9o Fed. 688 (D.C. Conn., I9II); United States v. 0.64 Acres of Land in Los Angeles County, 54 F. Supp. 562 (Cal., I944); see Foster v. United States, I45 F. 2d 873 (C.A. 8th, I944).

9 United States v. 3.544 Acres of Land, I47 F. $2 d$ d 596 (C.A. 3d, r945); Eagle Iake Improvement Co. v. United States, $14 x$ F. $2 \mathrm{~d} 562$ (C.A. 5th, I944); Washington Water Power Co. v. United States, I35 F. 2d 54I (C.A. gth, r943), cert. den. 320 U.S. 747 (r943); United States v. Foster, I3I F. 2d 3 (C.A. 8th, I942); United States v. Improved Premises Known as No. 46-70 McLean Avenue in City of Yonkers Westchester County, 54 F. Supp. 469 (N.Y., I944); Banner Milling Co. v. State, 24ㅇ N.Y. 533, I48 N.E. 668 (I925); Sawyer v. Commonwealth, I82 Mass. 245, 65 N.E. 52 (I902).

zo Kimball Laundry v. United States, 338 U.S. I (I949); Mitchell v. United States, 267 U.S. 34I (I925); McCormick, The Measure of Compensation in Eminent Domain, 2 Selected Essays on Constitutional Law 930, 944 (I938) [reprinted from I7 Minn. L. Rev. 46r (I933)]. Under the Supreme Court's theory, good will is not taken (except when the business is condemned and operated by the government) since it resided in the business, not the physical property. Only the property is taken, not the business, say the courts. Strong arguments can be made against this position, however, since good will is substantially attached to the physical place of business. This is especially true of retail stores. Good will depends to a great extent on business reputation. Yet a retail store transferring to a new location may have no reputation at the new site to induce patronage, and therefore it may suffer a genuine loss. Yet good will is certainly property and has a pecuniary interest. It is recognized as an asset in partnerships, Slater v. Slater, I75 N.X. I43, 67 N.E. 224 (r9०3), and may be sold or passed by will. Howard v. Taylor, 90 Ala. $24 \mathrm{I}, 8$ So. 36 ( $\mathrm{r} 890)$. If a condemnee can reasonably prove injury to good will, there appears no reason not to compensate him for it. 
to be inherent in any sale and should therefore be borne by the property owner. ${ }^{\text {II }}$

This policy has been partially justified by the notion of the voluntary sale which assumes that the seller is willing to dispose of his property at the time of the condemnation at a price equal to the highest prevailing offer which the property would receive on the open market. ${ }^{22}$ In most cases this is simply not true. While public necessity forces the owner to sell his property at this price, many factors might deter him from selling immediately. ${ }^{\mathrm{r3}}$ Among these are his expectations as to future market conditions, his psychological attachment to the property, the general unavailability of other suitable property, and the necessity of remaining uncompensated for losses which under genuinely voluntary conditions of sale might have been minimized or eliminated.

Yet the fiction of the voluntary seller ignores these facts and the courts have persisted in talking about condemnation proceedings as if the parties were a willing seller and a willing buyer transacting business on the free, open market. ${ }^{14}$ As a result they have refused to permit juries to hear evidence of use value $^{15}$ or of any of the consequential costs which ordinarily would be considered by a seller before he decided to sell his property.

Another factor in this policy has been the courts' preoccupation with the word "property." This has resulted in the Fifth Amendment being interpreted as meaning that compensation should be paid only for property actually taken. ${ }^{16}$ Once this was decided it was quite natural that injury to other interests

Ix Gershon Bros. Co. v. United States, 284 Fed. 849 (C.A. 5th, I922); Pacific Live Stock Co. v. Warm Springs Irrigation District, 270 Fed. 555 (C.A. 9th, I92I); In re Post Office Site, 2IO Fed. 832 (C.A. 2d, I9I4). In United States v. Inlots, 26 Fed. Cas. 482 , No. 15,44I (C.C. Ohio, 1873 ), the court said, at 489 : "The claimants being bound by the conditions of their respective leases to remove their property at the end of their terms, the act of appropriation only changes the time when the removal should take place, but does not occasion the obligation to remove, and that, therefore, the government is not justly chargeable with the losses consequent upon removal. ..." Tie-in sales are a means often used to mitigate such losses. The value of the tie-in would be included in the selling price.

xa United States v. Miller, 3 I7 U.S. 369 (I943); United States v. Powelson, 3x9 U.S. 266 (I943); Olson v. United States, 292 U.S. 246 (I934); United States v. Chandler-Dunbar Co., 229 U.S. 53 (rgr3); Westchester County Park Commission v. United States, I43 F. 2d 688 (C.A. 2 d, I944), cert. den. 323 U.S. 726 (I944). If there is no market for the property at the time of taking, some other date must be used to fix its value. St. Joe Paper Co. v. United States, I55 F. 2 d 93 (C.A. 5th, I946). If there is no market price, expert opinion or some other means is used. Ir,000 Acres of Land v. United States, I52 F. 2 d 566 (C.A. 5th, 1945), cert. den. 328 U.S. 835 (I945).

${ }^{13}$ See 5 I L.R.A. 3 I9, 330, 33I, at IV (r900).

24 Olson v. United States, 292 U.S. 246 (I934); Morton Butler Timber Co. v. United States, 9r F. 2 d 884 (C.A. 6th, x937).

Is United States v. II Acres of Land, 54 F. Supp. 89 (N.Y., I944). Only "value" which is capable of transfer from owner to owner is compensable under the doctrine of Kimball Laundry v. United States, 338 U.S. I, 3 (I949).

${ }^{16}$ Monongahela Navigation Co. v. United States, I48 U.S. $3{ }^{2}$ (I893). The court in this case said that just compensation was payment for the property and not payment to the owner. It also argued that every other clause of the Fifth Amendment was personal except the eminent domain provision and that therefore the Constitution only requires payment for property 
attached to the property and additional losses suffered by the owner should be excluded from the basis of the award. Yet the Constitution mentions not only property, but also states that "just compensation" shall be paid. ${ }^{17}$ It would seem by any standard of justice that the property owner should be made whole for all reasonable losses suffered by him as a result of the condemnation, including financial after effects which may be quite extensive. ${ }^{8}$

While the general rule excluding payment for consequential losses has not been overturned, the Supreme Court has recognized the harshness of its policies by modifying its interpretation of the Fifth Amendment in certain instances where less than a fee has been condemned. Although the language of the Court gives lip service to prior precedents, the results in these cases constitute an unmistakable attempt to give compensation for all the damages suffered by the condemnees.

In United States v. General Motors Corp. ${ }^{19}$ the government condemned a longterm lease but returned tine premises with a large portion of the term unexpired. The lessee demanded payment for the costs of removing fixtures and machinery. The Court held that such removal costs could not be awarded per se, but that since there was only a temporary taking instead of the condemnation of a fee, the evidence of such expense was admissible as to the market value of the unexpired term..$^{20}$

In Kimball Laundry v. United States ${ }^{2 x}$ the Court went a step beyond the

taken and nothing more. In United States v. 25.936 Acres of Land, ${ }_{53}$ F. 2 d 277 (C.A. 3 d, I946), the court said that a condemnation proceeding was not a taking of rights of persons in the ordinary sense but an appropriation of the land or property itself. Therefore, all previous existing estates or interests in the land were obliterated.

${ }^{17}$ Mr. Justice Rutledge laid great emphasis on the word "just" in his concurring opinion in United States v. Petty Motor Co., 327 U.S. 372 (1946). He said, at 383 , that the Fifth Amendment is "an explicit mandate for payment of " $j u s t$ compensation." "He also stressed that the reason for awarding removal costs in United States v. General Motors Corp., 323 U.S. 373 (r945), was "to give substance, in practical effect to the Amendment's explicit mandate for payment." "Just" has been interpreted as requiring that a citizen be left no poorer (or richer) than he would have been before the property was taken. United States v. Indian Creek Marble Co., 40 F. Supp. 8II (Tenn., I94r). However, with the Court's emphasis on paying only for property, this phrase loses much of its equitable sound.

${ }^{28}$ The value of consequential losses claimed by the condemnee in Kimball Laundry $v$. United States, 338 U.S. I (1949), was $\$ 340,000$. The lower court denied this claim and awarded $\$ 300,000$ in damages. The lower court was reversed by the Supreme Court. Consult 37 Calif. I. Rev. 680, 684 (I949), noting the Kimball case.

${ }^{x 9} 323$ U.S. 373 (I945). The Chief Justice and Justices Frankfurter and Murphy were absent and took no part in the proceedings. Justice Douglas, joined by Justice Black, concurred. They seemed willing to follow the equity of the award, but felt that an act of Congress was a more desirable prerequisite to abandoning a firm rule than the distinction between permanent and temporary takings.

${ }_{20}$ This award of necessity can be made only after the government returns the property, since before that time it is not known whether or not the entire lease will be used up.

${ }^{2 x} 338$ U.S. I (1949). The Chief Justice, and Justices Douglas, Black and Reed dissented. They rejected the distinction between a temporary and permanent taking and insisted that a new constitutional doctrine was being forged. Justice Rutledge concurred with the majority. For an excellent note on the Kimball case see 37 Calif. L. Rev. 680 (1949). 
General Motors decision by admitting an element of going-concern value as a consequential business loss. The laundry had been condemned for a term of years for Army use, and the owners contended that compensation should be made for the injury to their trade routes. ${ }^{22}$ The Court granted the award by reasoning that the intangible trade routes were property that had a transferable and independent value not unlike actual physical property. Since the government pays for property taken, the owners were compensated.

These decisions are a step in the right direction, although they have been limited to temporary takings. ${ }^{23}$ However, the attempt of the Court in the General Motors case to award removal costs through the machinery of "the market value for property taken" standard only adds to the existing confusion. Furthermore, the award does not consider whether the removal of the machinery resulted in its unproductive use during the term of the government's occupancy. Nor is there any logical correlation between the difference in the market value of the premises with machinery and without it, and the cost of transporting the machinery to and from the property.

The reasoning of both decisions is also suspect, for the Court's justification of the result because of a temporary taking does not harmonize with prior authority. Removal costs have never been given when a fee was condemned nor have damages been granted for a loss affecting business opportunities or one caused by cancellation of contracts. Yet the awarding of removal costs in a temporary taking seems just another way of compensating a lessee for a loss of profits resulting from the decreased market value of the property occasioned by the lack of machinery and fixtures. The prohibition against permitting contract damages in a permanent taking is likewise ignored, for in effect the decision tends to prevent extensive loss on the lease.

In the Kimball situation, going-concern value has not been admitted as an element of compensation on the theory that the owner might have re-established himself in the business and thus have retained the beneficial interest. ${ }^{24}$ It was at

22 "The term ... serves as a general designation both for the lists of customers built up by solicitation over the years and for the continued hold of the Laundry upon their patronage." Kimball Laundry v. United States, 338 U.S. I, 8 (1949).

${ }^{23}$ The Court has been consistent within the rule of the General Motors case. In United States v. Petty Motor Co., 327 U.S. 372 (I946), a lease was condemned with an option to shorten the period of occupancy. The government subsequently consumed the entire lease and the Court denied removal costs, since there was no unexpired term. In United States v. Westinghouse, 339 U.S. 26 I (1950), the government condemned a lease with a right to renew its occupancy. Again the entire lease was used up and the Court denied removal costs. Justice Jackson dissented. He believed that the use of the option was unjust because it gave the government a chance to hedge against inflation. They could either exercise the option in the event of a rising market or recondemn the property if the market were falling and thus pay a lower market price.

These three cases cover the entire range of possibilities with leases, leaving the law clear on the matter. If the government returns part of an unexpired lease, removal costs will be admitted as an element of the market value of the unexpired term. Otherwise they will be denied regardless of the form of the option used by the government.

24 Bothwell v. United States, 254 U.S. 23I (I920). Orgel states that "[I]n the eminentdomain cases, unless the entire enterprise is being condemned, the owner is not entitled to 
least possible for the owner to have opened a new laundry or to have leased the trade routes so as to preserve their value. However, under Mitchell v. United States $^{25}$ the rule of no compensation had applied even when the business had been totally destroyed and it was impossible to find suitable premises for the transfer of this intangible interest. Justice Frankfurther recognized the barrier of this precedent to the Kimball doctrine, but he was unwilling to overrule the case and endeavored to distinguish the Mitchell case on the grounds that the range of alternatives open to a condemnee in a temporary taking is so narrow as to justify a difference in result. This rationalization of a temporary taking is insufficient to account for such a significant deviation from the established rule. As a result the Mitchell case appears to have been substantially overruled sub silentio.

The problem in these cases has been to reconcile the conflict of interests between the government as buyer and the government as protector of the seller's rights. Reluctance to require payment for consequential damages may have been based in part upon a doubt as to the workability of any rule that would accurately measure these losses. In the Kimball and General Motors cases, the Supreme Court was evidently impressed with the seriousness of these losses and decided that justice required that they be measured..$^{26}$ To hide this basic change of position, they seized upon the analysis of the temporary taking to distinguish the prior cases.

The Supreme Court admits that "[ $t]$ he Constitution and the Statutes do not define the meaning of just compensation. ${ }^{{ }_{27} 7}$ The condemnation proceeding is ideally suited to consider all types of losses ${ }^{28}$ and the mode of proof by which the losses are to be evaluated should not deter the Court from seeing that justice is done. By using the reasonableness test, the courts could admit evidence

compensation for the value of the business over and above the property taken.... [Goingconcern value] is an element of the value of the entire enterprise for which no compensation is awardable and it is therefore immaterial." Orgel, Valuation under Eminent Domain \& I9I $\left(x_{936)}\right.$

${ }^{25} 267$ U.S. 341 (I925).

${ }^{26}$ In the Kimball case, Justice Frankfurter, writing the majority opinion, said at ${ }_{5}$, "[I]t would be unfair to deny compensation for a demonstrable loss of going-concern value upon the assumption that an even more remote possibility - the temporary transfer of going-concern value-might have been realized." The Court thus undermined the maxim of eminent domain law that in taking the plant you do not take the business. Other unsound beliefs, such as the fiction that a "voluntary sale" to the government under eminent domain is just like a voluntary sale to a private citizen, have become a part of the interpretation of the Fifth Amendment. They only serve to hamper a real understanding of the problems involved and to provide the courts with a rationalization for awarding unjust compensation.

27 United States v. Petty Motor Co., 327 U.S. 372, 377 (I946).

${ }^{28}$ In the average condemnation proceeding, proof of market value is usually introduced through expert testimony. Usually three experts testify for each side as to the value of the property for its highest and best use. In evaluating consequential losses it would seem that expert testimony could similarly be used to estimate injury to good will, contract losses and other intangible injuries. 
of removal costs, ${ }^{29}$ injury to going-concern value, good will and contract losses, the difference between reasonable-use value and the cost of other similar premises and the value of any other property rights injured as a result of the condemnation. Such a test would exclude any payment for sentimental attachment to the property, psychological disorders incurred because of the condemnation, excessive removal costs, ${ }^{30}$ and other claims which are likely to induce fraud or are so speculative that any attempt at a valuation would be a blind guess.

The cost of paying for property seized for public use should be shared equally by all the taxpayers. The Fifth Amendment was not meant to be a subsidy of the community by the individual.

\section{INFORMAL CONDEMNATION AND THE REVIVAL OF THE CRESS CASE}

In recent years there has been a trend toward increased federal immunity to claims by riparian owners on tributaries of navigable streams for damages resulting from federal flood control activities. The case of United States $v$. Kansas City Life Insurance Co. ${ }^{2}$ may well be considered a reaction against this trend. Respondent's farmland, located on a non-navigable tributary one and one-half miles from the Mississippi River, was rendered unfit for agricultural purposes by a stoppage of drainage due to the raised level of the tributary. This was the result of the construction of a dam by the federal government on the Mississippi. ${ }^{3}$ Two issues were recognized by the majority: (I) May the government permanently raise a navigable stream to its ordinary high water mark without liability for damage to property beyond the bed of the stream; and (2)

29 One authority states that "it would seem that compensation for the cost of removal to a new site, within a reasonable distance, might be worked out in favor of the owner of the land by use of the doctrine that where only part of the land is taken, the measure of compensation is the difference between the value of the entire property before the taking and the value after the condemnation of the part not taken. Under this theory, the owner would recover the value of the land and improvements, less the value of the improvements required to be removed. Of course, this deduction would be diminished by the fact that the value of the improvements would be no greater than what they were after subtracting the cost of making them usable by moving them to a new location." McCormick, op. cit. supra note ro, at 947.

${ }^{3 \circ} \mathrm{A}$ person living in Chicago could not receive removal costs to California.

See Justice Douglas' dissent in United States v. Kansas City Life Insurance Co., 339 U.S. 799, 812 (r950); Frank, The United States Supreme Court: 1949-50, I8 Univ. Chi. L. Rev. I, I5-I8 (1950); Federal Eminent Domain Power in the Development of Water Projects, 50 Yale L.J. 668 (r94I); Fitts and Marquis, Liability of the Federal Government and its Agents for Injuries to Private Property Resulting from River Improvements, I6 Tenn. L. Rev. 80I, 813-24 (r94r).

339 U.S. 799 (I950). Justices Black, Douglas, Minton and Reed dissented.

3 Respondent's $I, 7$ Io acres on Dardenne Creek were destroyed by lack of drainage because of the raised level of the creek, although the Mississippi did not rise above the ordinary high water mark. The Court of Claims awarded \$22,519.60 with interest since r9.38. 